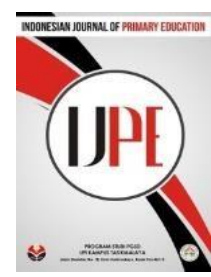

Vol. 2, No. 1 (2018) 30-37 ISSN: 2597-4866

Indonesian Journal of Primary Education

IJPE

\title{
Pembelajaran Ansambel Musik untuk Siswa Kelas Tinggi Sekolah Dasar
}

\author{
Resa Respati $^{1}$, Ulfah Samrotul Fuadah ${ }^{2}$ \\ Universitas Pendidikan Indonesia Kampus Tasikmalaya \\ *Corresponding author: respati@upi.edu; ulfah.sfuadah@gmail.com \\ Diterima 6 Mei 2018; Direview 9 Mei 2018; Diterima 17 Mei 2018 \\ Diterbitkan online 4 Juni 2018
}

\begin{abstract}
Abstrak
Pendidikan seni musik memberikan pelatihan untuk mengekspresikan dan mengapresiasikan seni secara kreatif untuk mengembangkan kepribadian siswa, sikap dan emosional, serta melatih kreativitas dengan memanfaatkan berbagai unsur yang ada dalam musik. Salah satu materi yang dipelajari yaitu ansambel. Dilapangan, masih banyak guru yang kebingungan dalam melaksanakan pembelajaran ansambel. Banyak faktor yang menghambat mulai dari bahan ajar, model pembelajaran, alat musik, serta motivasi. Dalam artikel ini dibahas mengenai pembelajaran ansambel musik untuk siswa kelas tinggi SD dengan model pembelajaran dan bahan ajar yang inovatif dan menyenangkan. Model pembelajaran yang digunakan yaitu model cooperative learning tipe jigsaw. Bahan ajar yang digunakan yaitu bahan ajar yang dirancang melalui tahap penelitian, sehingga bahan ajar tersebut telah disesuaikan dengan kemampuan siswa SD, dapat dipahami dengan baik, serta teruji kelayakannya. Berdasarkan kegiatan pembelajaran yang telah dilaksanakan melalui penelitian, siswa mengalami peningkatan cukup baik dalam bermain ansambel musik.
\end{abstract}

Kata Kunci: Ansambel Musik, Cooperative Learning, Jigsaw, Sekolah Dasar.

\section{PENDAHULUAN}

Droscher dalam Gunara (2008: 21) mengungkapkan bahwa “... pengajaran musik, berpikir kreatif, memecahkan masalah berani mengambil resiko, bekerja dalam tim dan berkomunikasi dengan baik, merupakan alat yang tepat untuk kebutuhan hidup di masa depan”. Dalam pernyataan tersebut dapat dipahami bahwa pendidikan musik memiliki peran penting untuk menunjang kehidupan seseorang dimasa depannya. Pendidikan seni musik memberikan pelatihan untuk mengekspresikan dan mengapresiasikan seni secara kreatif untuk mengambangkan kepribadian, mengembangkan sikap dan emosional, serta melatih kreativitas dengan memanfaatkan berbagai unsur yang ada dalam musik. Seni musik membentuk disiplin, toleran, sosialisasi, sikap demokrasi yang meliputi kepekaan terhadap lingkungan.

Dalam Badan Standar Nasional Pendidikan (2006: 8) disebutkan bahwa seni salahsatunya seni musik termasuk pada kelompok mata pelajaran estetika. Kelompok mata pelajaran ini dimaksudkan untuk meningkatkan sensitivitas, kemampuan mengekspresikan 
dan kemampuan mengapresiasi keindahan dan harmoni. Dengan kemampuan apresiasi dan ekspresi yang dimiliki, diharapkan siswa dapat mensyukuri hidup dan mampu menciptakan kebersamaan yang harmonis dalam kehidupan bermasyarakat.

Musik merupakan salah satu cabang seni yang menggunakan bunyi sebagai media (dalam Supriyatna dan Syukur, 2006: 2). Pendidikan seni musik memberikan pelatihan untuk mengekspresikan dan mengapresiasikan seni secara kreatif dalam bentuk bunyi untuk mengambangkan kepribadian siswa, mengembangkan sikap dan emosional siswa, dan melatih kreativitas dengan memanfaatkan berbagai unsur yang ada dalam musik. Pendidikan seni musik pun penting untuk meningkatkan salah satu kecerdasan yaitu kecerdasan musikal. Seperti yang tercantum dalam teori kecerdasan majemuk menurut Howard Gardner (dalam Hoerr, 2007: 14-15), kecerdasan tersebut yaitu kecerdasan linguistik, logika-matematika, musikal, kinestetik, spasial, interpersonal, intrapersonal, dan naturalis.

Dalam Badan Standar Nasional Pendidikan (2006, hlm. 186) disebutkan bahwa aspek seni musik yang dipelajari siswa pada jenjang sekolah dasar mencakup kemampuan untuk menguasai olah vokal, memainkan alat musik, dan apresiasi karya musik. Keterampilan yang harus dicapai oleh siswa tercantum dalam Kompetensi Dasar. Kompetensi dasar pada pembelajaran seni musik berarah pada pencapaian aspek yang telah disebutkan sebelumnya. Salah satu muatan materi yang tercantum dalam kompetensi dasar tersebut yaitu mengenai ansambel. Baik dalam kurikulum 2006 (KTSP) maupun kurikulum 2013, ansambel menjadi salah satu kompetensi yang harus dipelajari dan dikuasai siswa.

Materi ansambel terkandung dalam kompetensi dasar yang harus dipelajari dan dimiliki siswa. Pada kurikulum 2006 (dalam Badan Standar Nasional Pendidikan, 2006, hlm. 194), materi ansambel telah dikenalkan kepada siswa kelas III semester 2. Selanjutnya materi ansambel lebih diperdalam siswa di kelas $\mathrm{V}$ terkait materi ansambel sejenis dan ansambel gabungan dengan $\mathrm{SK}$ dan $\mathrm{KD}$ yang diuraikan dalam tabel 1.

\section{Tabel 1}

SK dan KD Kurikulum 2006 pada Materi Ansambel Kelas V SD (dalam Badan Standar Nasional Pendidikan, 2006, hlm. 194)

\begin{tabular}{|c|c|}
\hline Standar Kompetensi & Kompetensi Dasar \\
\hline \multicolumn{2}{|l|}{ Semester 1} \\
\hline $\begin{array}{l}\text { 3. Mengapresiasi karya } \\
\text { seni musik }\end{array}$ & $\begin{array}{c}\text { 3.2 Menjelaskan Makna } \\
\text { Ansambel sejenis }\end{array}$ \\
\hline $\begin{array}{l}\text { 4. Mengekspresikan diri } \\
\text { melalui karya seni } \\
\text { musik }\end{array}$ & $\begin{array}{l}\text { 4.1 Memainkan alat } \\
\text { musik ritmis dan } \\
\text { melodis sederhana } \\
\text { dalam bentuk } \\
\text { ansambel sejenis }\end{array}$ \\
\hline
\end{tabular}

\begin{tabular}{lrr}
$\begin{array}{l}\text { Mengapresiasi karya } \\
\text { seni musik }\end{array}$ & $\begin{array}{r}11.2 \\
\text { Menjelaskan makna } \\
\text { ansambel gabungan } \\
\text { 12. Mengekspresikan diri } \\
\text { melalui karya seni musik }\end{array}$ & $\begin{array}{l}\text { Memainkan alat } \\
\text { musik ritmis dan } \\
\text { melodis sederhana } \\
\text { dalam bentuk } \\
\text { ansambel gabungan }\end{array}$ \\
\hline Berdasarkan & fakta & dilapangan,
\end{tabular}
pembelajaran ansambel musik belum menjadi perhatian utama dan banyak guru kesulitan dalam melaksanakan pembelajarannya. Hal 
tersebut dipengaruhi oleh beberapa faktor yaitu bahan ajar, model pembelajaran, alat musik, serta motivasi. Bahan ajar yang tersedia sangat sedikit dan guru masih kesulitan memahami bahan ajar tersebut. Bahan ajar yang ada kurang fleksibel dan memiliki tingkat kesulitan yang cukup tinggi untuk disampaikan, dan akhirnya menyebabkan materi tersebut ditinggalkan dan siswa tidak dapat mengembangkan kemampuannya. Guru pun terkadang kebingungan dalam melaksanakan pembelajaran dan cenderung menggunakan model pembelajaran klasikal dan konvensional. Selain itu, fasilitas sekolah ikut menjadi hambatan dalam pelaksanaan pembelajaran ansambel musik.

Dalam pembelajaran ansambel musik, siswa harus dapat memainkan musik secara bersama-sama. Dengan hal itu, siswa akan mampu merasakan dan menyesuaikan permainannya dengan orang lain, belajar bekerjasama dan saling melengkapi. Kebanyakan pada pembelajaran yang dilaksanakan dilapangan, pembelajaran ansambel terpaku pada memainkan satu jenis alat musik secara bersama-sama dan bahkan hanya sebagian siswa yang bermain. Hal tersebut dipicu karena siswa tidak mempunyai alat musik dan sekolah belum memfasilitasi dengan baik. Dengan berbagai hambatan tersebut, akhirnya motivasi belajar ansambel musik pun menjadi sangat rendah. Berdasarkan hal tersebut, diperlukan suatu pembaharuan dalam belajar ansambel musik agar pembelajaran dapat dilaksanakan dengan baik dan efektif. Salah satunya dengan menggunakan bahan ajar ansambel musik yang telah dirancang berdasarkan penelitian dan model pembelajaran kooperatif tipe jigsaw.

\section{PEMBAHASAN}

\section{Ansambel Musik}

Sunardi (2013: 11) menyatakan bahwa, "Ansambel secara umum diartikan sebagai bentuk bermain musik bersama-sama". Ansambel Berasal dari bahasa Prancis yaitu Ensemble berarti bersama-sama (dalam Purnomo dan Subagyo, 2010: 71). Berdasarkan definisi tersebut, dapat disusun kesimpulan bahwa ansambel merupakan permainan musik yang dilakukan secara bersama-sama. Ansambel dapat dilakukan oleh dua orang atau lebih. Contoh ansambel seperti orkestra, band, paduan suara, duet, trio, dan sebagainya.

Gunara (2008, hlm.20) yang menyatakan bahwa "Fungsi pendidikan musik bagi kehidupan anak adalah untuk menolong mereka mencapai kesuksesan dalam bersosialisasi dan kehidupannya." Hal tersebut dapat diraih salahsatunya dengan bermain ansambel. Bermain musik secara ansambel memiliki banyak manfaat seperti memunculkan sikap tanggung jawab, bekerja sama dan harmonis antar siswa. Berdasarkan hasil penelitian yang telah dilakukan oleh Hartati, dkk. (2013, hlm. 33), setelah belajar bermain musik secara ansambel, sikap siswa yang mementingkan diri sendiri mulai 
berkurang kemudian berganti oleh sikap bekerja sama dalam satu tim ansambel yang harmonis.

Menurut bentuk penyajiannya, ansambel dibagi menjadi dua jenis yaitu ansambel sejenis dan ansambel gabungan (Purnomo dan Subagyo, 2010, hlm. 71). Kedua jenis ansambel tersebut dibedakan oleh alat musik yang digunakan. Berikut penjelasan kedua jenis ansambel.

\section{Musik ansambel sejenis}

Musik ansambel sejenis merupakan penyajian musik ansambel dengan menggunakan satu jenis alat musik. Contohnya seperti ansambel rekorder, ansambel perkusi, ansambel pianika dan sebagainya. Ansambel ini bisa berisi ansambel instrumen melodis atau ritmis.

\section{Musik ansambel campuran}

Musik ansambel campuran merupakan penyajian musik ansambel dengan menggunakan beberapa jenis alat musik. Contohnya ansambel yang berisi permainan rekorder, pianika, dan gitar. Alat musik yang digunakan dalam permainan ansambel dikelompokkan menjadi tiga kelompok berdasarkan peran dan fungsinya, yaitu: (1) alat musik melodis; (2) alat musik ritmis; dan (3) alat musik harmonis (Sunardi, 2013, hlm.11). pada jenjang sekolah dasar, siswa hanya belajar alat musik melodis dan ritmis saja. Hal tersebut karena alat musik harmonis memiliki kesulitan yang lebih tinggi dan memerlukan pengetahuan yang lebih kompleks.
Ansambel yang digunakan dalam pembelajaran ini yaitu ansambel campuran. Terdiri dari pemain pianika 1, pianika 2, perkusi, dan vokal. Lagu yang dibawakan telah diaransemen sederhana sehingga terbagi menjadi beberapa warna suara. Aransemen disesuaikan dengan kemampuan siswa dalam membaca notasi angka, sehingga siswa dapat membacanya meskipun tanpa bimbingan.

\section{Model Pembelajaran}

Kegiatan pembelajaran yang baik harus dirancang sedemikian rupa mulai dari model, pendekatan, strategi, metode, dan teknik pembelajarannya. Joyce (2009) menyatakan bahwa, "Model pembelajaran sebagai kerangka konseptual yang digunakan sebagai pedoman dalam melakukan pembelajaran". Kerangka konseptual berarti terdapat beberapa komponen di dalamnya. Komponenkomponen tersebut yaitu pendekatan, strategi, media dan teknik pembelajaran. model pembelajaran merupakan serangkaian pendekatan, strategi, metode dan teknik yang membentuk pola untuk diterapkan dalam sebuah pembelajaran. Arends (2008) menjelaskan ada lima macam model pembelajaran, yaitu (1) model pembelajaran langsung (direct instruction), (2) model pembelajaran kooperatif (cooperative learning), (3) model pembelajaran berbasis masalah (problem based learning), (4) model pembelajaran diskusi (discussion), dan (5) model pembelajaran strategi (strategi learning).

Model pembelajaran yang digunakan 
dalam pembelajaran ini yaitu model pembelajaran cooperative learning. Pembelajaran cooperative learning merupakan salah satu model pembelajaran kelompok yang memiliki aturan-aturan tertentu (Syarifuddin, 2011: 212). Aturan tersebut terdiri dari prinsip dan ketentuan sebagai ciri khas pembelajaran kooperatif. Menurut Stahl (Syarifuddin, 2011: 215), prinsip pembelajaran kooperatif yaitu; (1) perumusan tujuan belajar siswa harus jelas; (2) peneriman yang menyeluruh oleh siswa tentang tujuan belajar; (3) ketergantungan yang bersifat positif; (4) interaksi yang bersifat terbuka; (5) tanggung jawab individu; (6) kelompok bersifat heterogen; (7) interaksi sikap dan perilaku sosial yang positif; (8) tindak lanjut; dan (9) kepuasan dalam belajar. prinsip-prinsip tersebut harus menjadi perhatian supaya tujuan pembelajaran kooperatif dapat mencapai tujuan dengan baik.

Model pembelajaran kooperatif memiliki banyak tipe atau teknik salah satunya yaitu tipe jigsaw. Pembelajaran kooperatif tipe jigsaw adalah model pembelajaran dengan menggunakan pengkelompokkan/tim kecil yaitu yang terdiri antara empat, enam, bahkan sampai delapan orang yang mempunyai latar belakang yang berbeda (Syarifuddin, 2011: 212). Ada dua penamaan kelompok yaitu kelompok asal dan kelompok ahli. Kelompok asal adalah kelompok awal yang dibentuk dengan anggota yang heterogen. Kelompok ahli adalah kumpulan dari perwakilan setiap kelompok awal yang diberi tugas khusus yang sama. Dalam kelompok ahli tersebut, siswa berdiskusi mengenai materi atau permasalahan yang sama lalu kemudian siswa kembali bergabung dengan kelompok asal dan menyampaikan hasil diskusinya.

Pembelajaran kooperatif tipe jigsaw memiliki langkah-langkah tertentu. Berikut langkah-langkah pembelajaran kooperatif menurut Slavin dan Stahl (Syarifuddin, 2011: 219) dan Nina (2015):

1. merancang rencana pembelajaran (menyampaikan tujuan, motivasi, dan membentuk kelompok asal);

2. menyajikan informasi;

3. mengorganisasikan kelompok (membentuk kelompok ahli);

4. membimbing diskusi lalu siswa kembali bergabung dengan kelompok asal;

5. memberikan kuis; dan

6. memberikan penghargaan kelompok.

\section{Pembelajaran Ansambel Musik}

Pembelajaran ansambel musik ini menggunakan model pembelajaran yang diadaptasi dari pembelajaran cooperative learning tipe jigsaw. Pembelajaran dapat dilaksanakan dalam 2 pertemuan. Pertemuan pertama terdiri dari pemberian teori ansambel, pengelompokkan dan latihan bersama. Pertemuan kedua terdiri dari pemantapan dan presentasi kelompok. Sebelumnya siswa telah diberikan arahan oleh guru untuk membuat kelompok yang terdiri dari 7 orang. Setiap kelompok membawa alat musik seperti pianika, rekorder dan stik drum. Kelompok 
ini merupakan kelompok asal, yang didalamnya memuat siswa untuk memainkan instrument musik yang berbeda.

Kegiatan pembelajaran terdiri dari tiga kegiatan utama yaitu pembukaan, inti, dan penutup. Pembukaan terdiri dari kegiatan mengucap salam, merapikan tempat duduk dan pakaian, berdoa dan pembiasaan, melakukan tepuk motivasi, dan melakukan apersepsi dengan tanya jawab bersama guru tentang berbagai hal yang mengarahkan pada kegiatan ansambel. Seperti pertanyaan "apakah kalian pernah melihat orang bermain musik secara bersama-sama?”, “apa perbedaan bermain musik secara bersamasama dengan bermain musik sendiri? Apa kelebihannya?". Kemudian guru memaparkan tujuan pembelajaran dan menjelaskan rangkaian kegiatan yang akan dilaksanakan. Siswa dipersilakan untuk duduk secara berkelompok.

Pada kegiatan inti, siswa melakukan eksplorasi. Siswa diberikan bahan ajar dan mencari informasi terkait berbagai hal tentang ansambel. Siswa bertanya jawab dengan guru terkait hal yang tidak dipahami dan keingintahuannya, menulis informasiinformasi tersebut dari bahan yang telah mereka pelajari. Adapun hal-hal yang dikaji dalam tahap ini diantaranya pemahaman ansambel, pengetahunan siswa terkait notasi musik serta keterampilan siswa dalam bermain instrumen musik. Pada dasarnya kegiatan eksplorasi ini bertujuan menggali pengetahuan awal siswa untuk selanjutnya dilakukan tritmen pembelajaran.

Pada tahap selanjutnya siswa bersiap-siap untuk melaksanakan kegiatan bermain musik ansambel. Guru mengarahkan siswa serta memberi tugas kepada masing-masing anggota pada kelompok asal. Pembagian tugas pada kelompok asal berdasarkan pembagian instrumen musik kelompok tersebut. Adapun setiap kelompok instrumen musik akan memainkan notasi lagu yang berbeda dengan kelompok instrumen musik lainnya. Guru memberikan notasi lagu kepada setiap kelompok, selanjutnya setiap anggota mendapatkan notasi lagu berdasarkan tugasnya masing-masing. Guru menjelaskan bahwa kelompok tersebut merupakan kelompok asal dan siswa akan tampil bersama kelompok asal.

Setelah siswa mengamati, memaknai dan memahami notasi lagu masing-masing, guru memerintahkan pada setiap anggota yang memiliki tugas sama dari semua kelompok untuk berkumpul dan membentuk kelompok ahli. Dalam kelompok ahli tersebut, setiap siswa belajar berdasarkan instrumen musik dan materi yang sama, serta saling mengajarkan satu dengan yang lainnya dibawah bimbingan guru. Kegiatan ini berlangsung sampai siswa dapat membaca notasi musik dan memainkan instrumen musiknya. Bagi kelompok perkusi, siswa dapat memainkan irama menggunakan tepukan tangan. Guru mengingatkan kepada setiap siswa agar mereka dapat menjalankan tugasnya dengan baik. 
Pada kegiatan elaborasi, siswa kembali berkumpul bersama kelompok asal. Dengan bimbingan guru, setiap siswa mencoba bermain musik secara bersama-sama dengan bagiannya masing-masing dan berusaha bermain secara harmonis. Pada tahap ini juga guru memilih salah satu siswa untuk mempresentasikan permainannya sesuai bagiannya. Siswa yang lain memberikan komentar dan saran, serta dilanjut dengan siswa lain selanjutnya.

Pada kegiatan konfirmasi, guru meluruskan cara memainkan alat musik sesuai notasi lagu jika ditemukan kesalahan atau terdapat siswa yang belum memahami materi. Selain itu, guru melakukan Tanya-jawab dengan siswa terkait bagian yang terdapat kesulitan untuk dimainkan dan berbagai hal yang belum dipahami siswa.

Pada kegiatan penutup, siswa bersamasama guru menyimpulkan hasil pembelajaran. guru memberikan penghargaan kepada kelompok yang dapat bekerjasama dengan baik dan memberikan hasil yang baik. Guru memberikan tugas kepada kelompok terutama pemain perkusi untuk mempersiapkan instrumen musik yang kreatif untuk dimainkan pada saat penampilan. Guru menyarankan kepada setiap kelompok agar rajin berlatih untuk memunculkan harmonisasi dan mempersiapkan diri untuk penampilan pada pertemuan selanjutnya.

Pembelajaran pada pertemuan kedua hampir sama dengan pembelajaran pertemuan pertama. Hanya saja siswa lebih fokus berlatih bersama kelompok asal untuk persiapan penampilan. Pada akhir pembelajaran, setiap kelompok menampikan hasil latihannya di depan kelas dan kelompok lain mengapresiasi. Guru memberikan penghargaan bagi kelompok terbaik, dan terkompak.

\section{SIMPULAN}

Pembelajaran ansambel musik akan lebih menyenangkan jika dikemas dengan baik dan didukung fasilitas yang baik pula. Guru harus dapat mengemas pembelajaran dengan menggunakan model pembelajaran yang baru dan rancangan pembelajaran yang dapat meningkatkan motivasi belajar siswa.

Salah satunya dengan menggunakan bahan ajar yang baik dan model pembelajaran yang baru. Model pembelajaran cooperative learning tipe jigsaw dapat memberikan situasi baru bagi siswa dalam belajar musik. Siswa belajar secara berkelompok, berdiskusi, dan saling mengajarkan satu sama lain supaya setiap siswa dapat memainkan alat musik sesuai partiturenya masing-masing. Siswa juga belajar bekerjasama, saling menyesuaikan, dan saling mendukung untuk menghasilkan alunan musik yang harmonis.

Supaya pembelajaran ansambel lebih menyenangkan, disarankan guru untuk dapat mengiringi permainan ansambel musik siswa dengan menggunakan alat musik harmonis atau guru dapat menggunakan musik digital (MIDI). Guru juga harus memiliki pengetahuan yang luas tentang ansambel, nada dan irama, aransemen lagu, dan 
komponen musik lainnya, supaya guru dapat menyiapkan pembelajaran lebih berkualitas.

\section{REFERENSI}

Arends, R. (2008). Learning to teach. Jogjakarta : Pustaka Pelajar

Badan Standar Nasional Pendidikan. (2006). Standar isi untuk satuan pendidikan dasar dan menengah. Jakarta: BSNP.

Gunara, S. (2008). Manfaat Pendidikan Seni bagi Anak. Dalam Suryatna, dkk. (Penyunting). Ritme. Vol 6 No 1 April 2008 19-26.

Hartati, dkk. (2013). Nilai-nilai pendidikan dalam permainan ansambel recorder. Jurnal Sendratasik, 1(3), hlm.31-43.

Hoerr, T.R. (2007). Buku kerja multiple intelligences. Bandung: Kaifa.

Joyce, B. dkk. (2009). Models of Teaching Model-Model Pengajaran. Yogyakarta. Pustaka Pelajar.

Nina, S. 2014. Pengertian, jenis, dan langkah-langkah model pembelajaran. [Online].

Tersedia: http://sakinahninaarz009.blogspot.co.id/ 2014/05/ pengertian-jenis-dan-langkahlangkah.html. [16 September 2015].

Purnomo, W., dan Subagyo, F. (2010). Terampil Bermusik untuk SMP dan MTs. Jakarta: Pusat Perbukuan Kemendiknas.

Sunardi. (2013). Meningkatan Hasil Belajar Bermain Musik Ansambel Melalui Metode Tutor Sebaya Kelas VIID SMP Negeri 14 Purworejo Tahun Pelajaran 2012/2013. (Skripsi). Jurusan pendidikan seni drama, tari, dan musik, Universitas Negeri Semarang, Semarang.

Supriyatna, N,. \& Syukur, S. (2006). Pendidikan seni musik. Bandung: UPI Press.
Syarifuddin, A. (2011). Model pembelajaran cooperative learning tipe jigsaw dalam pembelajaran. TA'DIB, XVI (02), hlm 209-226. 